\title{
THE EFFECT OF SILICON FOLIAR APPLICATION ON THE DEVELOPMENT OF SEASONAL ORNAMENTAL PLANTS. PART I: Sanvitalia speciosa 'Sunbini', Verbena 'Patio Blue' AND Portulaca umbraticola 'Duna Red'
}

\author{
Regina Dębicz, Katarzyna Wróblewska \\ Department of Horticulture, Wroclaw University of Environmental and Life Sciences, \\ pl. Grunwladzki 24 A, 50-363 Wrocław, Poland \\ e-mail: regina.debicz@up.wroc.pl
}

Received: 17.06.2011

\begin{abstract}
Silicon is known as an element stimulating plant immunity and resistance to unfavorable conditions. Additional treatment with silicon may also cause a positive change in plant performance, improving the quality of ornamental plants. In the years 2009-2010, a two-factorial experiment was conducted involving three cultivars of seasonal ornamental plant species: creeping zinnia Sanvitalia speciosa 'Sunbini', vervain Verbena 'Patio Blue', and purslane Portulaca umbraticola 'Duna Red'. The first experimental factor was the concentration of Actisil

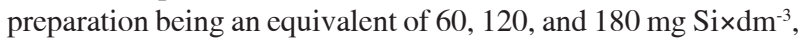
applied three times by spraying, the second one was the type of medium: peat substrate and peat substrate with sand. The experiment proved the beneficial effect of fertilization with silicon on plant development of Verbena and the number of shoots of all examined plant species. The higher concentrations of Actisil were applied, the higher number of shoots the plants developed. Plants treated with Actisil also produced a higher number of buds and flowers or inflorescences featuring an increased diameter. Plants cultivated in peat substrate flowered better.
\end{abstract}

Key words: silicon, Sanvitalia, Verbena, Portulaca, growth, flowering

\section{INTRODUCTION}

Silicon is one of the most commonly occurring chemical elements in nature. In spite of high silicon concentration in different types of soil, it is not an indispensable element for the growth and development of higher plants. Yet, recent research has proved that supplementary application of silicon positively influences many aspects of plant growth. It is a well-known fact that silicon is involved in plant tolerance against many stress factors: it increases manganese and heavy metal tolerance as well as resistance against pathogens, like fungi or herbivorous insects ( $\mathrm{Re}$ y nolds et al. 2009). Numerous papers give evidence that silicon acts in different plant species, although the main object of silicon research seems to be gramines, with special focus on rice. There have also been records documenting the above-mentioned role of silicon in ornamental plants, for example roses (Gill m a n et al. 2003) and poinsettia (M c Avoy and B ible, 1996). One of the most important facts is that silicon in the soil helps plants survive in the conditions of water shortage, as well. Drought resistance associated with silicon is explained by decreased transpiration in cells with higher silicon concentration ( $\mathrm{G}$ a o et al. 2006). All of these may influence plant development, for example shoot growth, flowering, or fruit production (M a r $\mathrm{schner}$ et al. 1990). Additional treatment with silicon seems to be justified in modern horticulture, as soilless media based on peat substrate are mainly used during plant production.

The aim of our study was to assess the effect of foliar application of silicon contained in Actisil preparation on growth and development of three species of ornamental plants cultivated in two types of medium based on peat moss.

\section{MATERIAL AND METHODS}

In the years 2009-2010, an experiment was carried out to assess the effect of Actisil preparation, containing $0.6 \%$ of silicon in the form of $\mathrm{H}_{4} \mathrm{SiO}_{4}$, on growth and development of three seasonal species: creeping zinnia Sanvitalia speciosa Lam. 'Sunbini', vervain Verbena Voss. 'Patio Blue' from Temari 
Patio group, and purslane Portulaca umbraticola Kunth. 'Duna Red'.

Treatments: A two - factorial experiment was established according to a randomized block design, in three replications, each of them involving 10 plants. The first factor was the concentration of Actisil preparation: $0.1,0.2$, and $0.3 \%$ being an equivalent of 60,120 ,

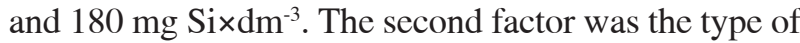
medium: ready-to-use peat substrate with the following


$\mathrm{K}-263 ; \mathrm{Ca}-1120$, as well as peat substrate with sand at the rate of 3:1 (by volume), containing [in $\mathrm{mg} \mathrm{dm}^{-3}$ ]: $\mathrm{N}-\mathrm{NO}_{3}-45 ; \mathrm{P}-87 ; \mathrm{K}-200 ; \mathrm{Ca}-1160$. Media salinity was 803 and $738 \mu \mathrm{S} \times \mathrm{cm}^{-1}$, respectively, and their $\mathrm{pH}$ (determined in distilled water, with the water to medium ratio 2:1, V:V) equalled 6.28 and 6.47 , respectively. Young plants originating from licensed nurseries, propagated by using shoot cuttings, were transplanted on $10^{\text {th }}$ of March 2009 and on $8^{\text {th }}$ of March 2010 from multi - pots to $9 \mathrm{~cm}$ diameter pots, filled with prepared medium and placed in a greenhouse on tables, at $20 \mathrm{x}$ $20 \mathrm{~cm}\left(25 \times \mathrm{m}^{-2}\right)$ spacing. Plants were sprayed with Actisil solution three times, with weekly intervals, from $20^{\text {th }}$ of March (in the first and the second experimental year). Control treatments involved plants not sprayed with the solution containing silicon. Plants were grown in a greenhouse heated to $18-20^{\circ} \mathrm{C}$ and they were fertilized once a week with a compound fertilizer Florovit at $1 \%$ concentration in the amount of $150 \mathrm{~cm}^{3}$ per pot. In order to supplement the lower concentration of nutrients during the first fertilization, plants cultivated in peat substrate with sand were additionally fertilized with Florovit solution (1\%) at a volume of $60 \mathrm{~cm}^{3}$ per plant, introducing: $30 \mathrm{mg} \mathrm{N}, 20 \mathrm{mg} \mathrm{P}$ and $40 \mathrm{mg} \mathrm{K}$.

Data recording and analysis: Plant growth and flowering were assessed on the $18^{\text {th }}$ of May 2009 and $17^{\text {th }}$ of May 2010 on the basis of the following measurements: length of main shoot, length and number of lateral shoots, plant diameter, number of buds and flowers or inflorescences, as well as the diameter of the latter ones. The chlorophyll content of leaves was determined after extraction in $80 \%$ acetone (A r n o n, 1949). Absorption was measured using a spectrophotometer (WPA, S106) at 645 and $663 \mathrm{~nm}$, and chlorophyll content [in $\mathrm{mg} \times \mathrm{g}^{-1}$ f.w.] was calculated according the following equation: chlorophyll $\mathrm{a}+\mathrm{b}=8.02\left(\mathrm{~A}_{663}\right)+20.21$ $\left(\mathrm{A}_{645}\right)$. Experimental results were statistically analysed using analysis of variance for two-factorial experiment, at a significance level of $\alpha=0.05$. To estimate the significance of differences, t-Duncan test was used.

\section{RESULTS AND DISCUSSION}

For producers of marketable balcony plants with hanging stems, the most appreciated features, indicating the decorative values of plants ready for sale, are as fol- lows: length and number of shoots, plant diameter, and number of flowers. Previous studies of different plants have proved that treating plants with Actisil praparation, when producing transplants, has a beneficial effect on the vegetative condition and flowering of young plants (Wraga and Dobrowolska, 2007), as well as the process of rooting (B a b e l e w s k i, 2008).

Our experiment demonstrated that plant treatment with silicon contained in Actisil did positively influence plant growth and development of Verbena 'Patio Blue'. Plant shoots were longer as the concentration of the solution that the plants were sprayed with was higher. There was also observed better branching expressed by increased plant diameter and higher number of lateral shoots. In comparison to the control treatment, the number of shoots produced by plants sprayed with Actisil at the highest concentration $(0.3 \%)$ increased approximately 2.5 times (Table 1 ). The advantageous effect of Actisil on the number of lateral shoots was also recorded for the remaining plant varieties. $\mathrm{Sa}$ nvitalia 'Sunbini' and Portulaca 'Duna Red' were characterized by better branching when they were treated with the preparation at a higher concentration (Table 2 and 3). In Sanvitalia Actisil additionally stimulated lateral shoot elongation, which directly translated into increased plant diameter (Table 2). A positive influence of Actisil preparation in Portulaca 'Duna Red', regarding the same features, was recorded only at the highest concentration of Actisil (0.3\%). Solutions of lower silicon content negatively affected lateral shoot length of this cultivar. No effect of silicon contained in Actisil on main shoot length was proved in the case of Portulaca. Similarly, the results of the research on plant treatment with silicon conducted so far have not always been univocal. The positive effect of Actisil at a concentration of 0.2 on the diameter of pansy Viola $\mathrm{x}$ wittrockiana Gams ex Kappert was also found by W r a g a and D o bro w o l s k a (2007). This preparation improved the shape of pot chrysanthemum as well, although it affected plant height and diameter in different ways (S t a r t e k et al. 2006). In case of multiflora rose Rosa multiflora Thunb. ex Murray, the application of Actisil did stimulate production of secondary lateral shoots and increased plant weight (H e t m a n et al. 2007).

The vegetative development of the studied plant varieties also depended on the type of medium. Better growth was observed in plants cultivated in peat substrate than in ones grown in peat and sand mixture. Taking into account most of the examined characteristics, the above-mentioned differences ranged below $10 \%$ or they were not significant. The only exception was the number of lateral shoots in Sanvitalia which was higher by $10.6 \%$ in plants cultivated in peat substrate.

In the papers published so far, it was also proved that, apart from stimulating vegetative growth, silicon favorably affected flowering, but it depended 
on the form of silicon and its concentration, as well as the type of application. Silicon introduced into liquid medium in hydroponic gerbera production did increase the yield of flowers graded Class I. Inflorescences also featured stiffer peduncles ( $\mathrm{S}$ a v v a s et al. 2002), while foliar application of $\mathrm{NaSiO}_{3}$ at a concentration of $150 \mathrm{mg} \times \mathrm{dm}^{-3}$ caused deformations of inflorescences and shortening of peduncles ( $\mathrm{Kamenidou}$ et al. 2010). Diverse effects of silicon on flowering of sunflower Helianthus annuиs 'Ring of Fire' cultivated in a greenhouse was reported by $\mathrm{Kamenidou}$ et al. (2008). In their experiments, the effect of Si supplementation on flowering varied from beneficial to detrimental, depending on the source of $\mathrm{Si}$ and concentration. In our investigations, it was found that the diameter of vervain inflorescences was smaller after being treated with Actisil at $0.1 \%$ (Fig. 1). In case of Sanvitalia and Portulaca, flower or inflorescence diameter increased with a higher concentration of silicon preparation (Fig. 1). As a result of spraying with Actisil, all the taxa had a higher number of buds and flowers than the control plants. The most abundant flowering was observed in plants treated with the solution of Actisil at a $0.3 \%$ concentration (Fig. 2). The strong influence of Actisil may result from the increased level of gibberellin $\mathrm{GA}_{3}$ induced by $\mathrm{Si}$, which was detected in wheat shoots ( $\mathrm{H}$ an a f y A hmed et al. 2008). This growth regulator is responsible for flowering induction or intensification in many plant species and is widely used for this purpose in plant production ( $\mathrm{N} \mathrm{o}$ wak and Grzesik, 1997).

Flowering of the examined species depended on the type of medium. The latter did not influence $\mathrm{Sa}$ nvitalia inflorescence diameter, while the flowers of Portulaca and the inflorescences of vervain were bigger by $2 \mathrm{~mm}$ in plants growing in peat substrate (Fig. 3 ). The same medium had a positive effect on abundance of flowering in all the examined species, yet the strongest effect was recorded in the case of Portulaca umbraticola (Fig. 4).

Plants treated with silicon are often characterized by a more intensive colour of leaves resulting from increased chlorophyll content (Wraga and Dobrowolska, 2007). Our results supported this thesis in case of Sanvitalia and Verbena. Irrespective of year and type of medium, chlorophyll content in leaves of creeping zinnia was higher in plants treated with Actisil at higher concentrations. On the other hand, Actisil decreased chlorophyll content in purslane leaves (Tab. 4).

Table 1

Morphological features of Verbena 'Patio Blue' depending on Actisil concentration and type of medium

\begin{tabular}{|c|c|c|c|c|c|c|c|c|c|c|c|c|c|}
\hline \multirow{4}{*}{$\begin{array}{l}\text { Concentration } \\
\qquad \%] \\
\text { (C) }\end{array}$} & \multirow{4}{*}{$\begin{array}{l}\text { Year } \\
\text { (A) }\end{array}$} & \multicolumn{12}{|c|}{ Feature of the plant } \\
\hline & & \multicolumn{3}{|c|}{ Length of main shoot $[\mathrm{cm}]$} & \multicolumn{6}{|c|}{ Number of lateral shoots Length of lateral shoots [cm] } & \multicolumn{3}{|c|}{ Diameter of plants [cm] } \\
\hline & & \multicolumn{3}{|c|}{ Type of medium (B) } & \multicolumn{3}{|c|}{ Type of medium (B) } & \multicolumn{3}{|c|}{ Type of medium (B) } & \multicolumn{3}{|c|}{ Type of medium (B) } \\
\hline & & $\mathrm{P}^{*}$ & PS* & $\begin{array}{l}\text { Mean } \\
(\mathrm{AxC})\end{array}$ & $\mathrm{P}^{*}$ & PS* & $\begin{array}{l}\text { Mean } \\
(\mathrm{AxC})\end{array}$ & $\mathrm{P}^{*}$ & PS* & $\begin{array}{l}\text { Mean } \\
(\mathrm{AxC})\end{array}$ & $\mathrm{P}^{*}$ & PS* & $\begin{array}{l}\text { Mean } \\
(\mathrm{AxC})\end{array}$ \\
\hline \multirow{2}{*}{ Control } & 2009 & 21.1 & 18.4 & 19.8 & 5.0 & 5.2 & 5.1 & 14.3 & 15.3 & 14.8 & 19.1 & 19.7 & 19.4 \\
\hline & 2010 & 23.8 & 19.8 & 21.8 & 5.4 & 5.0 & 5.2 & 15.3 & 14.0 & 14.7 & 18.5 & 18.0 & 18.3 \\
\hline Mean $(\mathrm{BxC})$ & & 22.5 & 19.1 & 20.8 & 5.2 & 5.1 & 5.2 & 14.8 & 14.7 & 14.7 & 18.8 & 18.9 & 18.8 \\
\hline \multirow{2}{*}{$0.1 \%$} & 2009 & 26,0 & 25.4 & 25.7 & 6.0 & 6.5 & 6.3 & 15.8 & 16.8 & 16.3 & 20.1 & 19.9 & 20.0 \\
\hline & 2010 & 26.0 & 25.0 & 25.5 & 6.1 & 6.5 & 6.3 & 15.9 & 14.7 & 15.3 & 21.5 & 19.8 & 20.6 \\
\hline Mean (BxC) & & 26.0 & 25.2 & 25.6 & 6.1 & 6.5 & 6.3 & 15.9 & 15.8 & 15.8 & 20.8 & 19.9 & 20.3 \\
\hline \multirow{2}{*}{$0.2 \%$} & 2009 & 29.1 & 29.4 & 29.3 & 7.3 & 7.6 & 7.5 & 18.9 & 20.5 & 19.7 & 25.5 & 25.9 & 25.7 \\
\hline & 2010 & 30.5 & 26.8 & 28.7 & 10.1 & 10.6 & 10.4 & 21.2 & 20.0 & 20.6 & 27.9 & 25.2 & 26.6 \\
\hline Mean $(\mathrm{BxC})$ & & 29.8 & 28.1 & 28.9 & 8.7 & 9.1 & 8.9 & 20.1 & 20.3 & 20.1 & 26.7 & 25.5 & 26.1 \\
\hline \multirow{2}{*}{$0.3 \%$} & 2009 & 36.8 & 33.6 & 35.2 & 8.0 & 8.2 & 8.1 & 20.0 & 22.2 & 21.1 & 30.1 & 31.5 & 30.8 \\
\hline & 2010 & 36.8 & 33.6 & 35.2 & 17.1 & 15.5 & 16.3 & 23.7 & 22.5 & 23.1 & 31.0 & 28.0 & 29.5 \\
\hline Mean $(\mathrm{BxC})$ & & 36.8 & 33.6 & 35.2 & 12.6 & 11.9 & 12.2 & 21.9 & 22.3 & 22.1 & 30.6 & 29.8 & 30.2 \\
\hline Mean (B) & & 28.8 & 26.5 & & 8.1 & 8.1 & & 18.1 & 18.3 & & 24.2 & 23.5 & \\
\hline \multicolumn{2}{|c|}{$\mathrm{LSD}_{0.05} ; \mathrm{NIR}_{0.05}$} & \multicolumn{3}{|c|}{$\begin{aligned} \mathrm{B} & =0.6 \\
\mathrm{C} & =0.8 \\
\mathrm{AxC} & =1.1 \\
\mathrm{~B} \mathrm{C} & =1.1\end{aligned}$} & \multicolumn{3}{|c|}{$\begin{aligned} \mathrm{B} & =\text { r.n.; n.s. } \\
\mathrm{C} & =0.3 \\
\mathrm{AxC} & =0.4 \\
\mathrm{BxC} & =0.4\end{aligned}$} & \multicolumn{3}{|c|}{$\begin{aligned} \mathrm{B} & =\text { n.s. } \\
\mathrm{C} & =0.5 \\
\mathrm{AxC} & =0.6 \\
\mathrm{~B} \times \mathrm{C} & =0.6\end{aligned}$} & \multicolumn{3}{|c|}{$\begin{aligned} \mathrm{B} & =0.5 \\
\mathrm{C} & =0.7 \\
\mathrm{AxC} & =1.0 \\
\mathrm{BxC} & =\text { r.n..; n.s. }\end{aligned}$} \\
\hline
\end{tabular}

* P means peat substrate, PS means peat substrate with sand in 3:1 ratio 
Table 2

Morphological features of Sanvitalia speciosa 'Sunbini' depending on Actisil concentration and type of medium

\begin{tabular}{|c|c|c|c|c|c|c|c|c|c|c|c|c|c|}
\hline \multirow{4}{*}{$\begin{array}{c}\text { Concentration } \\
{[\%]} \\
\text { (C) }\end{array}$} & \multirow{4}{*}{$\begin{array}{c}\text { Year } \\
\text { A }\end{array}$} & \multicolumn{12}{|c|}{ Feature of the plant } \\
\hline & & \multicolumn{12}{|c|}{ Length of main shoot $[\mathrm{cm}]$ Number of lateral shoots Length of lateral shoots $[\mathrm{cm}]$ Diameter of plants $[\mathrm{cm}]$} \\
\hline & & \multicolumn{3}{|c|}{ Type of medium (B) } & \multicolumn{3}{|c|}{ Type of medium (B) } & \multicolumn{3}{|c|}{ Type of medium (B) } & \multicolumn{3}{|c|}{ Type of medium (B) } \\
\hline & & $\mathrm{P}^{*}$ & PS* & $\begin{array}{l}\text { Mean } \\
(\mathrm{AxC}) \\
\end{array}$ & $\mathrm{P}^{*}$ & PS* & $\begin{array}{l}\text { Mean } \\
(\mathrm{AxC})\end{array}$ & $\mathrm{P}^{*}$ & PS* & $\begin{array}{l}\text { Mean } \\
(\mathrm{AxC})\end{array}$ & $\mathrm{P}^{*}$ & PS* & $\begin{array}{l}\text { Mean } \\
(\mathrm{AxC})\end{array}$ \\
\hline \multirow{2}{*}{ Control } & 2009 & 31.7 & 30.4 & 31.4 & 13.4 & 13.8 & 13.6 & 17.7 & 16.0 & 16.9 & 27.1 & 23.2 & 25.2 \\
\hline & 2010 & 26.8 & 23.0 & 24.9 & 12.9 & 12.0 & 12.5 & 17.0 & 15.5 & 16.3 & 26.8 & 23.0 & 24.9 \\
\hline \multicolumn{2}{|l|}{ Mean $(\mathrm{BxC})$} & 29.3 & 26.7 & 28.0 & 13.2 & 12.9 & 13.0 & 17.4 & 15.8 & 16.6 & 26.9 & 23.1 & 25.0 \\
\hline \multirow{2}{*}{$0.1 \%$} & 2009 & 20.3 & 21.2 & 20.8 & 14.5 & 14.1 & 14.3 & 16.3 & 16.6 & 16.5 & 28.5 & 29.8 & 29.2 \\
\hline & 2010 & 28.9 & 26.2 & 27.6 & 13.9 & 13.0 & 13.4 & 18.0 & 16.9 & 17.5 & 27.1 & 26.8 & 26.9 \\
\hline \multicolumn{2}{|l|}{ Mean $(\mathrm{BxC})$} & 24.6 & 27.6 & 24.2 & 14.2 & 13.6 & 13.9 & 17.2 & 16.8 & 17.0 & 27.8 & 28.3 & 28.0 \\
\hline \multirow{2}{*}{$0.2 \%$} & 2009 & 27.0 & 26.8 & 26.9 & 15.5 & 14.3 & 14.9 & 20.6 & 18.8 & 19.7 & 29.4 & 31.0 & 30.2 \\
\hline & 2010 & 30.5 & 28.9 & 29.7 & 14.9 & 14.0 & 14.5 & 20.5 & 19.8 & 20.2 & 29.5 & 30.5 & 30.0 \\
\hline \multicolumn{2}{|l|}{ Mean $(\mathrm{BxC})$} & 26.9 & 29.7 & 28.3 & 15.2 & 14.2 & 14.7 & 20.6 & 19.3 & 19.9 & 29.5 & 30.7 & 30.1 \\
\hline \multirow{2}{*}{$0.3 \%$} & 2009 & 34.2 & 33.4 & 33.8 & 20.7 & 15.6 & 18.2 & 25.2 & 21.4 & 23.3 & 33.2 & 34.5 & 33.9 \\
\hline & 2010 & 35.9 & 35.0 & 35.5 & 18.9 & 16.0 & 17.5 & 26.0 & 25.9 & 26.0 & 33.9 & 34.0 & 34.0 \\
\hline \multicolumn{2}{|l|}{ Mean $(\mathrm{BxC})$} & 33.8 & 35.5 & 34.6 & 19.8 & 15.8 & 17.8 & 25.6 & 23.6 & 24.6 & 33.6 & 34.2 & 33.9 \\
\hline \multicolumn{2}{|l|}{ Mean (B) } & 29.4 & 28.1 & & 15.6 & 14.1 & & 20.2 & 18.9 & & 29.4 & 28.9 & \\
\hline \multicolumn{2}{|c|}{$\mathrm{LSD}_{0.05} ; \mathrm{NIR}_{0.05}$} & \multicolumn{3}{|c|}{$\begin{aligned} \mathrm{B} & =0.4 \\
\mathrm{C} & =0.4 \\
\mathrm{xC} & =0.9 \\
\mathrm{xC} & =0.9\end{aligned}$} & \multicolumn{3}{|c|}{$\begin{aligned} \mathrm{B} & =0.6 \\
\mathrm{C} & =0.8 \\
\mathrm{AxC} & =\text { r.n.; n.s. } \\
3 \mathrm{xC} & =1.3\end{aligned}$} & \multicolumn{3}{|c|}{$\begin{aligned} \mathrm{B} & =0.6 \\
\mathrm{C} & =0.8 \\
\mathrm{AxC} & =1.2 \\
\mathrm{BxC} & =\text { r.n.; n.s. }\end{aligned}$} & \multicolumn{3}{|c|}{$\begin{aligned} \mathrm{B} & =\text { n.s. } \\
\mathrm{C} & =0.8 \\
\mathrm{AxC} & =1.2 \\
\mathrm{BxC} & =1.2\end{aligned}$} \\
\hline
\end{tabular}

* $\mathrm{P}$ means peat substrate, PS means peat substrate with sand in 3:1 ratio

Table 3

Morphological features of Portulaca umbraticola 'Duna Red' depending on Actisil concentration and type of medium

\begin{tabular}{|c|c|c|c|c|c|c|c|c|c|c|c|c|c|}
\hline \multirow{4}{*}{$\begin{array}{c}\text { Concentration } \\
{[\%]} \\
\text { (C) }\end{array}$} & \multirow{4}{*}{$\begin{array}{c}\text { Year } \\
\text { (A) }\end{array}$} & \multicolumn{12}{|c|}{ Feature of the plant } \\
\hline & & \multicolumn{3}{|c|}{ Length of main shoot $[\mathrm{cm}]$} & \multicolumn{3}{|c|}{ Number of lateral shoots } & \multicolumn{3}{|c|}{ Length of lateral shoots $[\mathrm{cm}]$} & \multicolumn{3}{|c|}{ Diameter of plants $[\mathrm{cm}]$} \\
\hline & & \multicolumn{3}{|c|}{ Type of medium (B) } & \multicolumn{3}{|c|}{ Type of medium (B) } & \multicolumn{3}{|c|}{ Type of medium (B) } & \multicolumn{3}{|c|}{ Type of medium (B) } \\
\hline & & $\mathrm{P}^{*}$ & PS* & $\begin{array}{l}\text { Mean } \\
(\mathrm{AxC})\end{array}$ & $\mathrm{P}^{*}$ & PS* & $\begin{array}{l}\text { Mean } \\
(\mathrm{AxC})\end{array}$ & $\mathrm{P}^{*}$ & PS* & $\begin{array}{l}\text { Mean } \\
(\mathrm{AxC})\end{array}$ & $\mathrm{P}^{*}$ & PS* & $\begin{array}{l}\text { Mean } \\
(\mathrm{AxC})\end{array}$ \\
\hline \multirow{2}{*}{ Control } & 2009 & 26.5 & 28.3 & 27.4 & 13.6 & 12.4 & 13.0 & 15.6 & 15.7 & 15.7 & 30.4 & 27.2 & 28.8 \\
\hline & 2010 & 22.3 & 22.0 & 22.2 & 13.5 & 13.9 & 13.7 & 12.0 & 10.0 & 11 & 24.5 & 23.0 & 23.8 \\
\hline Mean $(\mathrm{BxC})$ & & 24.4 & 25.2 & 24.8 & 13.6 & 13.2 & 13.3 & 13.8 & 12.9 & 13.3 & 27.5 & 25.1 & 26.3 \\
\hline \multirow{2}{*}{$0.1 \%$} & 2009 & 26.0 & 25.5 & 25.8 & 15.7 & 16.1 & 15.9 & 11.6 & 9.9 & 10.8 & 26.7 & 27.9 & 27.3 \\
\hline & 2010 & 23.5 & 22.7 & 23.1 & 17.6 & 14.0 & 15.8 & 12.5 & 11.9 & 12.2 & 25.5 & 23.6 & 24.6 \\
\hline Mean (BxC) & & 24.8 & 24.1 & 24.4 & 16.7 & 15.1 & 15.8 & 12.1 & 10.9 & 11.5 & 26.1 & 25.6 & 25.9 \\
\hline \multirow{2}{*}{$0.2 \%$} & 2009 & 24.7 & 24.3 & 24.5 & 18.2 & 17.1 & 17.7 & 12.5 & 10.8 & 11.6 & 25.8 & 26.9 & 26.4 \\
\hline & 2010 & 24.9 & 24.3 & 24.6 & 18.2 & 15.0 & 16.6 & 13.5 & 12.9 & 13.2 & 26.5 & 25.0 & 25.8 \\
\hline Mean $(\mathrm{BxC})$ & & 24.8 & 24.3 & 24.6 & 18.2 & 16.1 & 17.1 & 13.0 & 11.9 & 12.4 & 26.2 & 26.0 & 26.1 \\
\hline \multirow{2}{*}{$0.3 \%$} & 2009 & 23.0 & 23.0 & 23.0 & 18.7 & 18.2 & 18.5 & 13.8 & 12.0 & 12.9 & 25.7 & 25.5 & 25.6 \\
\hline & 2010 & 26.6 & 25.5 & 26.1 & 18.7 & 16.9 & 17.8 & 15.6 & 16.0 & 15.8 & 28.5 & 27.5 & 28.0 \\
\hline Mean (BxC) & & 24.8 & 24.3 & 24.5 & 18.7 & 17.6 & 18.1 & 14.7 & 14.0 & 14.4 & 27.1 & 26.5 & 26.8 \\
\hline Mean (B) & & 24.7 & 24.5 & & 16.8 & 15.4 & & 13.4 & 12.4 & & 26.9 & 25.8 & \\
\hline \multicolumn{2}{|c|}{$\mathrm{LSD}_{0.05} ; \mathrm{NIR}_{0.05}$} & \multicolumn{3}{|c|}{$\begin{aligned} \mathrm{B} & =\text { r.n.; n.s. } \\
\mathrm{C} & =\text { r.n.; n.s. } \\
\text { AxC } & =\text { r.n.; n.s. } \\
\text { BxC } & =\text { r.n.; n.s. }\end{aligned}$} & \multicolumn{3}{|c|}{$\begin{aligned} \mathrm{B} & =0.4 \\
\mathrm{C} & =0.6 \\
\mathrm{AxC} & =0.9 \\
\mathrm{BxC} & =\text { r.n.; n.s. }\end{aligned}$} & \multicolumn{3}{|c|}{$\begin{aligned} \mathrm{B} & =0.3 \\
\mathrm{C} & =0.4 \\
\mathrm{AxC} & =0.5 \\
\mathrm{BxC} & =\text { r.n..; n.s. }\end{aligned}$} & \multicolumn{3}{|c|}{$\begin{aligned} \mathrm{B} & =0.3 \\
\mathrm{C} & =0.5 \\
\mathrm{AxC} & =0.6 \\
\mathrm{BxC} & =0.6\end{aligned}$} \\
\hline
\end{tabular}

* $\mathrm{P}$ means peat substrate, $\mathrm{PS}$ means peat substrate with sand in 3:1 ratio 
Table 4

Chlorophyll content in leaves of Sanvitalia speciosa 'Sunbini', Verbena 'Patio Blue', and Portulaca umbraticola 'Duna Red' depending on Actisil concentration and type of medium, expressed as the sum of chlorophyll $\mathrm{a}$ and $\mathrm{b}\left[\mathrm{mg} \times \mathrm{g}^{-1}\right.$ of fresh weight]

\begin{tabular}{|c|c|c|c|c|c|c|c|c|c|c|}
\hline \multirow{4}{*}{$\begin{array}{c}\text { Concentration } \\
{[\%]}\end{array}$} & \multirow{4}{*}{ Year } & \multicolumn{9}{|c|}{ Species and variety } \\
\hline & & \multicolumn{3}{|c|}{ Sanvitalia speciosa 'Sunbini' } & \multicolumn{3}{|c|}{ Verbena 'Patio Blue' } & \multicolumn{3}{|c|}{ Portulaca umbraticola 'Duna Red } \\
\hline & & \multicolumn{3}{|c|}{ Type of medium } & \multicolumn{3}{|c|}{ Type of medium } & \multicolumn{3}{|c|}{ Type of medium } \\
\hline & & $\mathrm{P}^{*}$ & PS* & Mean & $\mathrm{P}^{*}$ & PS* & Mean & $\mathrm{P}^{*}$ & PS* & Mean \\
\hline \multirow{2}{*}{ Control } & 2009 & 0.96 & 1.06 & 1.01 & 1.14 & 0.98 & 1.06 & 0.33 & 0.23 & 0.28 \\
\hline & 2010 & 1.09 & 1.13 & 1.11 & 1.52 & 0.79 & 1.16 & 0.39 & 0.85 & 0.62 \\
\hline Mean & & 1.03 & 1.10 & 1.06 & 1.33 & 0.86 & 1.11 & 0.36 & 0.54 & 0.45 \\
\hline \multirow{2}{*}{0.1} & 2009 & 1.13 & 0.93 & 1.03 & 1.15 & 1.17 & 1.16 & 0.29 & 0.31 & 0.30 \\
\hline & 2010 & 1.41 & 1.23 & 1.32 & 1.41 & 1.53 & 1.47 & 0.50 & 0.48 & 0.49 \\
\hline Mean & & 1.27 & 1.08 & 1.18 & 1.28 & 1.35 & 1.32 & 0.40 & 0.40 & 0.40 \\
\hline \multirow{2}{*}{0.2} & 2009 & 1.17 & 1.01 & 1.09 & 0.90 & 1.08 & 0.99 & 0.36 & 0.23 & 0.30 \\
\hline & 2010 & 1.23 & 1.46 & 1.35 & 1.42 & 1.34 & 1.33 & 0.50 & 0.38 & 0.44 \\
\hline Mean & & 1.20 & 1.24 & 1.22 & 1.16 & 1.21 & 1.19 & 0.43 & 0.31 & 0.37 \\
\hline \multirow{2}{*}{0.3} & 2009 & 1.21 & 0.99 & 1.10 & 1.06 & 1.15 & 1.11 & 0.34 & 0.36 & 0.35 \\
\hline & 2010 & 1.48 & 1.25 & 1.37 & 1.46 & 1.48 & 1.47 & 0.49 & 0.44 & 0.47 \\
\hline Mean & & 1.35 & 1.12 & 1.24 & 1.26 & 1.32 & 1.29 & 0.42 & 0.40 & 0.41 \\
\hline
\end{tabular}

* P means peat substrate, PS means peat substrate with sand in 3:1 ratio



Fig. 1. The effect of Actisil concentration on the diameter of inflorescences of Sanvitalia speciosa 'Sunbini' and Verbena 'Patio Blue' as well as flowers of Portulaca umbraticola 'Duna Red' (means for two years) [cm] 


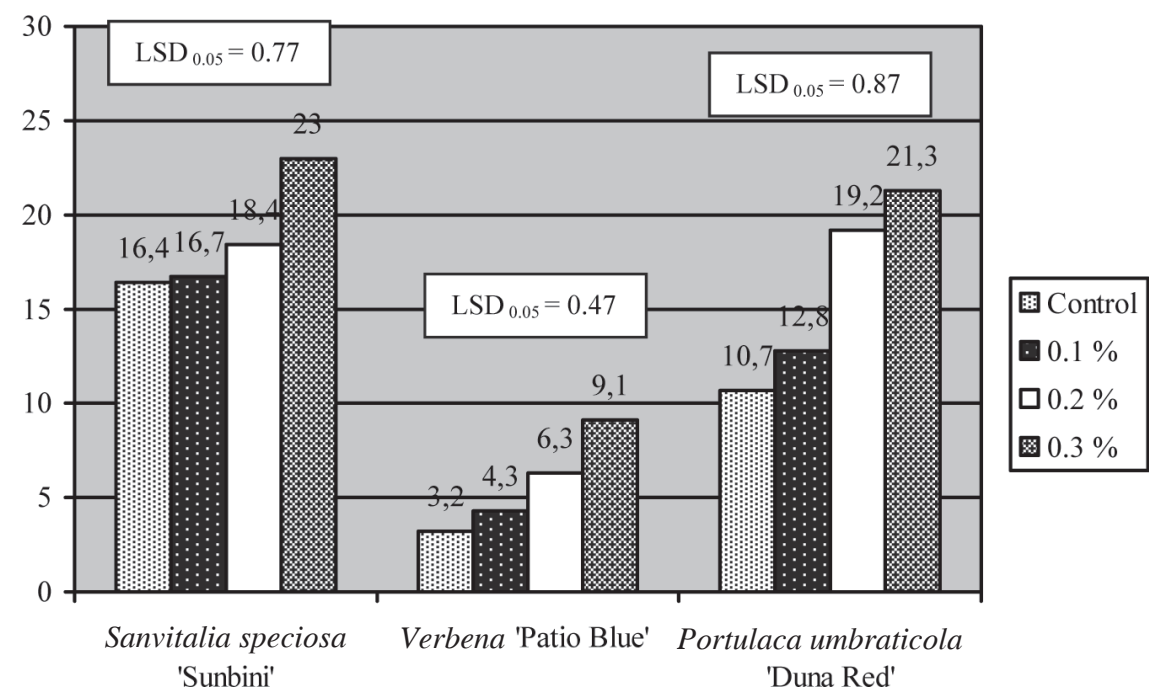

Fig. 2. The effect of Actisil concentration on the number of buds and inflorescences of Sanvitalia speciosa 'Sunbini' and Verbena 'Patio Blue' as well as buds and flowers of Portulaca umbraticola 'Duna Red' (means for two years)

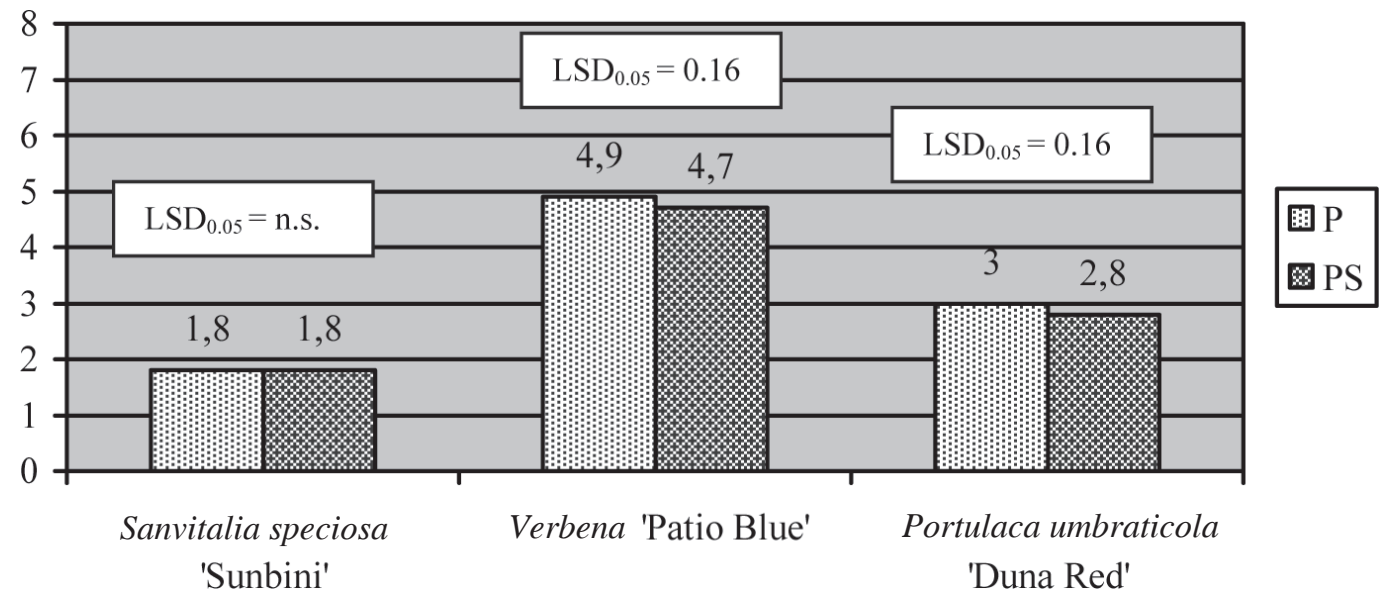

Fig. 3. The effect of type of medium on the diameter of inflorescences of Sanvitalia speciosa 'Sunbini' and Verbena 'Patio Blue' as well as flowers of Portulaca umbraticola 'Duna Red' (means for two years) [cm]

Legend: $\mathrm{P}$ means peat substrate, PS means peat substrate with sand in 3:1 ratio

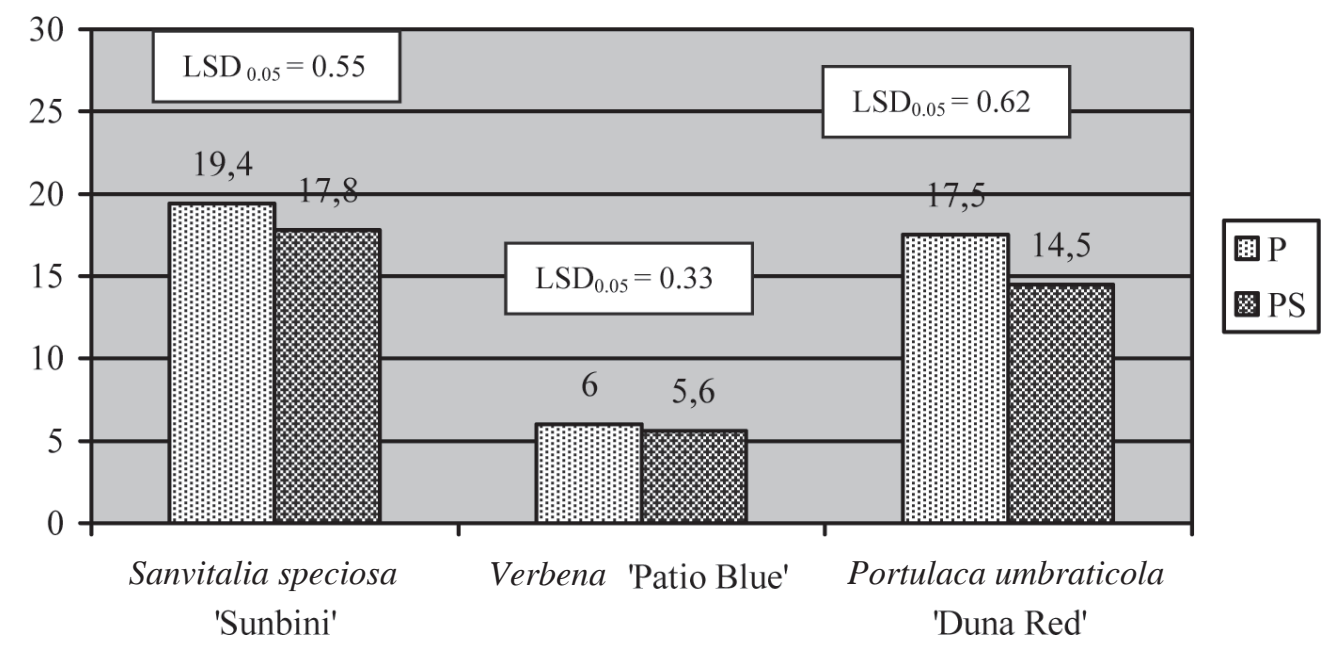

Fig. 4. The effect of type of medium on the number of buds and inflorescences of Sanvitalia speciosa 'Sunbini' and Verbena 'Patio Blue' as well as buds and flowers of Portulaca umbraticola 'Duna Red'(means for two years)

Legend: P means peat substrate, PS means peat substrate with sand in 3:1 ratio 


\section{CONCLUSIONS}

1. Silicon contained in Actisil preparation did positively affect the number of lateral shoots in Sanvitalia speciosa 'Sunbini', Verbena 'Patio Blue', and Portulaca umbraticola 'Duna Red'. The number of lateral shoots increased with the increased concentration of the preparation.

2. Foliar treatment with Actisil had a beneficial effect on all the examined features of Verbena 'Patio Blue'.

3. The investigated plant cultivars, after being sprayed with Actisil, produced a higher number of buds and flowers or inflorescences with an increased diameter compared to the control plants. The most abundant flowering was recorded for plants treated with fertilizer solution at a $0.3 \%$ concentration.

4. Better growth and flowering were observed in plants cultivated in peat substrate than in peat and sand mixture.

\section{REFERENCES}

Arnon D.I., 1949: Copper enzymes in isolated chloroplasts. Poly-phenoloxidase in Beta vulgaris. Plant Physiol. 24: 1-15.

Bąbelewski P., 2008: Wpływ preparatu Actisil na jakość ukorzenionych sadzonek wybranych taksonów jałowca (Juniperus sp.). / The infuence of Actisil on the quality of rooted cuttings of some juniperus taxa (Juniperus sp.). Zesz. Probl. Post. Nauk Rol. 525: 27- 32. (in Polish)

Gao X., Zou C., Wang L. Zhang F., 2006: Silicon decreases transpiration rate and conductance from stomata of maize plants. J. Plant Nutr. 29: 1637-1647

Gillman J.H., Zlesak D.C., and Smith J.A., 2003: Applications of potassium silicate decrease black spot infection in Rosa hybrida 'Meipelta' (Fuschia Meidland). Hort Sci. 38: 1144-1147.

Hanafy Ahmed A.H., Harb E.E., Higazy M.A., Morgan Sh.H., 2008: Effect of silicon and boron foliar application on wheat plants grown under saline soil conditions. Int. J. Agri. Res. 3 (1): 1-26.

Hetman J., Maliborska M., Iwanow T., 2007: Wpływ Actisilu i sposobu uprawy na wzrost róży wielkokwiatowej Rosa multiflora. XI Ogólnopolska Konferencja Szkółkarska: Problemy i perspektywy produkcji szkółkarskiej roślin ozdobnych, ISiK- Skierniewice: 53-65 (in Polish).

Kamenidou S., Cavins T.J., Marek S., 2008: Silicon supplements affect horticultural traits of greenhouse-produced ornamental sunflowers. Hort Sci. 43 (1): 236-239.

Kamenidou S., Cavins T.J., Marek S., 2010: Silicon supplements affect floricultural quality traits and elemental nutrient concentrations of greenhouse produced gerbera. Sci. Hort. 123: 390-394.
Marschner H., Oberle H., Cakmak I., Romheld V., 1990: Growth enhancement by silicon in cucumber (Cucumis sativus) plants depends on imbalance in phosphorus and zinc supply. Plant Soil. 124: 211-219.

McAvoy R.J., Bible B.B., 1996: Silica sprays reduce the incidence and severity of bract necrosis in poinsettia. Hort Sci. 31 (7): 1146-1149.

Nowak J., Grzesik M., 1997: Regulatory roślinne w uprawie roślin ozdobnych. / Plant regulators in ornamental plant cultivation. [In:] Regulatory wzrostu i rozwoju roślin. / Plant growth and development regulators, ed. Jankiewicz L.S., Państwowe Wydawnictwo Naukowe, Warszawa: 117-118 (in Polish).

Reynolds O.L., Keeping M.G., Meyer J.H., 2009: Silicon-augmented resistance of plants to herbivorous insects: a review. Ann. Appl. Biol. 155: 171-186.

Savvas, D., Manos, G., Kotsiras, A., Souvalio t i s, S., 2002: Effects of silicon and nutrient-induced salinity on yield, flower quality and nutrient uptake of gerbera grown in a closed hydroponic system. J. Appl. Bot. 76: 153-158.

Startek L., Placek M., Wraga K., 2006: Wpływ preparatu Hydro Plus Actisil na niektóre cechy chryzantem uprawianych w doniczkach. / The influence of HydroPlus ActiSil on some traits of pot chrysanthemum cultivars. Zesz. Probl. Post. Nauk Rol. 510: 619-626 (in Polish).

Wraga K., Dobrowolska D., 2007: Ocena wpływu preparatu Actisil na cechy morfologiczne i wartość dekoracją rozsad dwóch odmian bratka ogrodowego z grupy Fancy. Część I. Wzrost roślin i wielkość liści. / The estimation of effect of Actisil on morphological traits and decorative value of seedlings two garden pansy cultivars from Pansy Groups. Part. I. Plants growth and leaf size. Rocz. AR Pozn. CCCLXXXIII, Ogrodn. 41: 229-233 (in Polish).

\section{Wpływ dolistnego traktowania krzemem na rozwój sezonowych roślin ozdobnych. Część I: sanwitalia okazała Sanvitalia speciosa 'Sunbini', werbena ogrodowa Verbena 'Patio Blue' i portulaka cieniolubna Portulaca umbraticola 'Duna Red'}

\section{Streszczenie}

Krzem jest znany jako pierwiastek pobudzający odporność roślin i ich wytrzymałość na niekorzystne warunki środowiska. Dodatkowe traktowanie roślin krzemem może wywoływać korzystne zmiany w ich wyglądzie, poprawiając jakość roślin ozdobnych. Dwuczynnikowe doświadczenie z trzema taksonami ozdobnych roślin sezonowych: sanwitalii 
okazałej Sanvitalia speciosa 'Sunbini', werbeny ogrodowej Verbena 'Patio Blue' i portulaki cieniolubnej Portulaca umbraticola 'Duna Red' przeprowadzono w latach 2009-2010. Pierwszym czynnikiem doświadczenia było stężenie preparatu Actisil odpowiadające

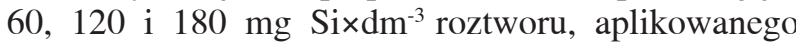
trzykrotnie $\mathrm{w}$ formie oprysku, drugim typ podłoża: substrat torfowy oraz substrat torfowy $\mathrm{z}$ piaskiem w proporcji 3:1.
W przeprowadzonym doświadczeniu wykazano korzystny wpływ dokarmiania krzemem na rozwój wegetatywny werbeny oraz na liczbę pędów bocznych wszystkich badanych gatunków. Ich liczba była tym większa im wyższe było stężenie preparatu. Badane taksony roślin w wyniku opryskiwania Actisilem miały większą liczbę paków i kwiatów lub kwiatostanów i o większej średnicy. Lepiej kwitły rośliny uprawiane w substracie torfowym. 